\title{
Predicting Individuals' Usage Intention of Social Commerce
}

\author{
Yazn Alshamaila ${ }^{1}$ \\ ${ }^{1}$ King Abdullah II School for Information Technology, The University of Jordan, Amman, Jordan \\ Correspondence: Yazan Alshamaileh, The University of Jordan, Business Information Technology, Amman, \\ Jordan. E-mail: Y.Shamaileh@ju.edu.jo
}

$\begin{array}{lcc}\text { Received: March 6, } 2018 & \text { Accepted: March 14, } 2018 & \text { Online Published: March 30, } 2018 \\ \text { doi:10.5539/mas.v12n4p204 } & \text { URL: https://doi.org/10.5539/mas.v12n4p204 }\end{array}$

\begin{abstract}
Online interactions pave the way for new streams of collaborations and support among connected users of social networking sites, and this collaboration is leveraged for business purposes. The purpose of this paper is to contribute to a growing body of research on social commerce by studying individuals' behavior from the consumer perspective of information technology innovations. By adopting "social support" and the technology acceptance model as a theoretical base, this study used a web-based questionnaire survey to collect data from 325 users of SNSs in Jordan. The data were then analyzed using Statistical Package for the Social Sciences regression. Jordan was selected because it is a country that has reported high SNS usage compared to other countries. The main factors that were identified as playing a significant role in individual adoption of social commerce were social commerce construct and perceived usefulness. This study did not find enough evidence that perceived ease of use and perceived information quality were a significant determinant of social commerce adoption. These findings have important implications and value for the academia, businesses managers, and social media specialists in terms of formulating better strategies for handling social commerce effects on businesses. For social media specialists, using the research model in this study can assist in increasing their understanding of why some individuals choose to adopt social commerce services. Additionally, business managers may need to improve their interaction with SNS users and develop a better understanding of how consumers use social commerce in the purchasing decision process. Based on our review of the existing scientific literature on social commerce, few empirical studies have been conducted to scientifically evaluate and explain the usage behavior of social commerce in Jordan. This paper contributes to the continuing research in social commerce adoption and diffusion in the individual context.
\end{abstract}

Keywords: social commerce, social networks sites, social support, TAM

\section{Introduction}

The increased popularity of social networking sites (SNSs) as a resourceful tool for socialization and information sharing has given rise to social commerce (s-commerce) as a relatively new branch of e-commerce (Liang \& Turban, 2011), where consumers and potential buyers use online media that support social interaction and user contributions to enhance the online purchase experience (Ng, 2013). SNSs such as Facebook, Twitter, and YouTube are popular across all borders, ages, genders, and ethnicities, and this is the main reason for the progress and innovation in this field (Qin, 2017). Apparently, consumers' social interaction via SNSs influences the opinions and behaviors of other consumers (Hajli, 2014). In particular, the more the social network friends of a user adopt a product, the more likely the user is to purchase it (Todri \& Adamopoulos, 2014), and vice versa. Wise business planning toward this emerging phenomenon (s-commerce) could lead to benefits. Because SNSs provide consumers with a platform to talk about different business brands, this develops a supportive climate in which consumers' intention to buy is promoted. In recent years, Jordan has reported a noteworthy advancement in internet penetration, smart mobile diffusion, e-commerce activities, and SNS usage. Jordan shows greater readiness for e-commerce than other developing countries (Yaseen, Dingley \& Adams, 2016). The use of SNSs in Jordan in general is high compared to other countries. According to a national survey across 40 countries, $90 \%$ of internet users in Jordan interact on social networks such as Facebook and Twitter as well as other popular country-specific social networks. This study shows that the percentage of social network users in emerging and developing countries like Jordan are higher compared to those in developed economies such as the United Kingdom, Russia, and France (Poushter, 2016). Jordan has more than 6.6 million cell phone subscriptions, which represents a $108 \%$ penetration rate, and $95 \%$ of Jordanians own cell phones (United States Department of 
Commerce, 2014). Even with the advancement of SNS usage among individuals, current studies on e-commerce have not yet made significant contributions to our understanding of s-commerce adoption. Hajli (2013) states that there is limited research in the area of s-commerce and more constructs should be examined to expand our knowledge. Part of the rationale for dedicating effort to studying this emerging trend is that this body of work has not reached the level of clarity that rivals the growth in internet and social networks diffusion. The main aim of this research project is to contribute to the relevant research field by providing initial insights through empirical assessment of the relevant theoretical framework. This study proposes a model with four components and then investigates the role played by these components on individual's intention to use s-commerce.

\section{Literature Review}

\subsection{Social Support}

Social support refers to an individual's experiences of being cared for, being responded to, and being helped by people in that individual's social group (Cobb, 1976). Social support theory has been systematically used in psychology, sociology, and health studies (Hajli, 2014). Such support, as a kind of enthusiastic feedback, can help a person feel better even if the support does not provide direct assistance to solve the person's problem. Such good experiences satisfy people in their social interactions with their supporters and help fulfill their social needs (Liang, Ho, Li \& Turban, 2011). The increased popularity of SNSs and web 2.0 as a resourceful tool for socialization and information sharing has given researchers the opportunity to use social support theory in the business information technology studies arena to understand users' behavior toward technology acceptance. The role of social support in s-commerce can be explained as follows: when social support exists in a social network, then it is most likely that users will share commercial information and recommendations as an extension of their sharing of other supportive information (Liang et al., 2011). In return, once a user perceives that fellow users have been concerned and ready to lend a hand in providing useful information, then acquiring or sharing valuable shopping information with others would be suitable (Crocker \& Canevello, 2008). Additionally, frequent information exchange and sharing among individuals can enhance the trust between SNS friends, which may positively affect the intention to conduct commercial activities.

\subsection{Social Commerce}

Internet connectivity improvement and smart mobile usage diffusion have advanced e-commerce because its use is constantly increasing. Social platforms give consumers an opportunity to support each other with information exchange and with the content they generate there (Hajli, 2015). These interactions pave the way for new streams of collaboration and support among connected users of SNSs, and when that collaboration is used for business purposes (Swamynathan, Wilson, Boe, Almeroth, \& Zhao, 2008) then a new aspect of e-commerce arises - that is, s-commerce. According to (Liang \& Turban, 2011), s-commerce "refers to the delivery of e-commerce activities and transactions via the social media environment, mostly in social networks and by using Web 2.0 software" (p.6). Researchers such as Hajli (2015) describe s-commerce as a new subset of e-commerce that enables shoppers to generate content via social media tools. Research has shown that most people tend to believe that using SNSs would enhance their job performance and other communication activities (Zhang, Lu, Gupta \& Zhao, 2014). S-commerce is mediated by social networking (Jeppesen \& Molin, 2003) and is mostly related to online communities, which have grown rapidly (Lu, 2014). Advancements in using SNSs shape the postmodern view of consumers (Füller, MüHlbacher, Matzler \& Jawecki, 2009) wherein they show different kinds of support to each other by rating and reviewing different products and services, participating in discussion forums, sharing their experiences, and showing their positive and negative recommendations to other buyers. In other words, individuals are able to produce content and not just be absorbers of advertising content published by sellers (Shen \& Eder, 2013). This kind of information stays online for a long time; it can be archived, it is not easy to delete, and it increases in volume every day. The digital content produced in social networks is a powerful tool that gives consumers the power to communicate in an affordable way and to influence the actions of others by the information that they post on SNSs and on the seller's web page as well as on other web pages. Furthermore, an important attribute of s-commerce is the fact that one can easily learn how to communicate with friends and peers online (Noh, Lee, Kim\& Garrison, 2013). This is because SNSs are designed with user-friendliness in mind and because the number of people who use the Internet continues to grow each day. The development of modern smartphones that support the use of Internet and social networks has greatly increased the number of people who use the two. This explains why it is easy for one friend who understands the dynamics of s-commerce to take another friend through the entire process. 


\section{Research Model and Hypotheses}

\subsection{Technology Acceptance Model}

The technology acceptance model (TAM) is a mature model and has been validated in different contexts (Lai \& $\mathrm{Li}, 2005)$. TAM is an information system theory that states when users are presented with new technology, there are factors influencing their decisions about when and how to use it (Davis, 1989). Factors such as perceived usefulness and perceived ease of use are substantial in explaining the variance in users' intention. Users believe that by using new technology, their performance will improve - this is referred to as perceived usefulness it (Davis, 1989). The second reason for accepting technology is that users assume a given technology will be easy to use it (Davis, 1989) classifies this as perceived ease of use. The tradition of adding factors to TAM model is common (Venkatesh, Morris, GB. Davis\& FD. Davis, 2003) and in more general theories of human behavior (Conner \& Armitage, 1998). This research project extends TAM by adding the perceived information quality factor, and social commerce construct (SCC) based on social support theory.

The positive relationship between perceived ease of use and perceived usefulness on individuals' intention to use new information and communication (ICT) innovation has received considerable empirical support (Lou, Luo \& Strong, 2000). Pavlou (2003) reported that these two fundamental determinants have a significant influence on intention to shop online, which can be extended into investigations on user online behavior in acceptance of the businesses to consumer (B2C) model in e-commerce. The paths in TAM can also apply to e-commerce and s-commerce (Gefen, Karahanna \& Straub, 2003). N. Hijli (2015) stated that these paths can be applied in the s-commerce adoption model to develop an integrated model with the impact of social components. Accordingly, we can hypothesize the following:

H1: The user's perceived usefulness has a positive effect on the user's intention to use s-commerce.

H2: Perceived ease of use has a positive effect on the user's intention to use s-commerce.

\subsection{Perceived Information Quality}

The integrity of data entails having complete information and credible details about prices, quality of goods, and places where products for sale can be found (Hijli, Lin, Featherman \& Wang, 2014). Several studies (Kim, Ferrin \& Rao, 2009; Beldad, Jong \& Steehouder, 2010; Shih, 2004; Chang, Cheung \& Lai, 2005; Shen, Huang, Chu \& Liao, 2010; Flanagin \& Metzger, 2013) obtain consistent findings showing that information quality can positively or negatively affect e-commerce behavior and individuals' intention to buy online. Information quality is used to measure ICT innovation performance and ICT innovation satisfaction (Bailey \& Pearson, 1983; Srinivasan, 1985; Mahmood, 1987; Miller \& Doyle, 1987; Shih, 2004). Information quality is taken into consideration as an important factor when assessing the effects of web use, particularly when searching for products or services in e-commerce because businesses are communicating with their consumers by exchanging information online (Çelik \& Yilmaz, 2011). Besides the ease of use and usefulness beliefs, the usage intention of s-commerce can be affected by perceived information quality. This research extends TAM in the context of s-commerce. We propose a new construct (perceived information quality) to enhance the understanding of an individual's usage behavior of s-commerce. Therefore, we can establish the following hypothesis:

H3: Perceived information quality has a positive effect on the user's intention to use s-commerce

\subsection{Social Commerce Constructs}

SCCs are constructs derived through s-commerce such as online forums, communities, ratings, reviews, and recommendations (Hajli, 2014). First, consider rating and reviews. On product review websites or sections of pages where users can rate the product or service they received, individuals are able to write about their experiences and rate products usually on a previously given scale (Chen, Xu \& Whinston, 2011). At a later stage, these ratings and reviews can give broad information about the benefits or drawbacks of the product or service to any future potential consumer looking for more information. Recent attention has focused on highlighting the fact that the popularity of third-party product reviews is growing. This has led some researchers (e.g., Chen \& Xie, 2005) to argue that the notion that consumers need for advertising information is reduced because of third-party reviews. Nowadays, online reviews and ratings have become one of the most powerful influencers on purchasing decisions for merchants and particularly for consumers because they give a voice to customers while developing their confidence, which is otherwise lacking in the e-commerce space. Another example of a SCC likely to play an important role on s-commerce intentions is recommendations and referrals. Research shows that because customers cannot experience the products or services personally in an online context, they rely more on other consumers' experiences such as their product recommendations and referrals (Senecal \& Nantel, 2004). In a shopping mall, customers spend their time in stores and can interact with the staff, whereas in an online shop, it 
is a major challenge to create an environment that is as socially rich as a physical store (Kumar, Novak \& Tomkins, 2010). As an alternative, consumers commonly ask for recommendations and referrals from past customers to find the best option for a particular product or service. Potential consumers turn to online recommendations and referrals to obtain more information about the product or service before they purchase it because they sometimes need to get information quickly or cannot find such information in other locations. The third example of s-commerce is forums and communities. Online communities and Internet forums are social environments that facilitate social interaction between individuals who otherwise might never have the chance to communicate with each other. Members of online communities participate in different organized and/or spontaneous group activities and support other members through their social interactions on the provided platform (Bagozzi \& Dholakia, 2002). They use a range of social technologies, such as social networks, online communities, and other web 2.0 applications, to support other members with their experiences and/or information sharing. These communities allow people to obtain general information about products and services and to support each other in different ways ( $\mathrm{Lu}$, Zhao \& Wang, 2010), including providing detailed information. On SNSs, different types of online communities exist that specialize in specific sectors. These communities gather individuals who are frequently interested in the community's related information This type of information, which is created by other consumers, is a modern alternative to the word-of-mouth recommendations used in traditional markets (Park, Lee \& Han, 2007) . As a result, the last hypothesis in the study is as follows:

H4: Social commerce constructs have a positive effect on users' intention to use s-commerce.

\section{Methodology}

The objective of this study is to propose a model with four components to investigate individuals' intention to use s-commerce. The model suggests that when users are presented with s-commerce, a number of factors influence their decisions about how and when they will use it: notably, SCCs, perceived ease of use, perceived usefulness, and perceived information quality.

Table 1. Operationalization of key variables

\begin{tabular}{ccc}
\hline Concept & Operational measure & $\begin{array}{c}\text { Sources } \\
\text { Adapted from }\end{array}$ \\
\hline Perceived usefulness & Multi-items & Hajli (2012); Gefen et al. (2003) \\
\hline Perceived information quality & Multi-items & Lou et al. (2000); Shih (2004) \\
Social commerce construct & Multi-items & Hajli (2015) \\
Perceived ease of use & Multi-items & Gefen et al. (2003) \\
\hline
\end{tabular}

The items used for measuring the constructs were derived from operationalization used in prior empirical studies (Table 1) and were adapted to suit this research context, followed by pilot testing.

Table 2. Cross loadings and reliability analysis

\begin{tabular}{ccccc}
\hline Construct & Number of items & Item code & Factor loading & Cronbach's alpha \\
\hline Perceived usefulness (PU) & 3 & PU2 & 0.804 & 772.0 \\
& & PU1 & 0.799 & \\
Perceived information quality (PIQ) & 3 & PU3 & 0.686 \\
& & Q2 & 0.768 & 0.791 \\
Perceived ease of use (PE) & 3 & Q3 & 0.755 & \\
& & Q1 & 0.727 & 0.737 \\
Social commerce construct (SCC) & 3 & PE3 2 & 0.787 & \\
\hline
\end{tabular}




$\begin{array}{ll}\text { SCC3 } & 0.811 \\ \text { SCC1 } & 0.748\end{array}$

The results showed that questionnaire used in this study covered important aspects identified in the literature review. Regarding reliability, Cronbach's alpha coefficients for each of these constructs were calculated. It has been suggested that a minimum level of 0.6 for the reliability coefficient is preferred (Hair, Black, Babin, Anderson \& Tatham, 1998). Table 2 indicates an acceptable Cronbach's alpha value. The items included in the measurement device were translated to Arabic. A five-level Likert scale was adopted in the measurement device.

\subsection{Hypothesis Testing}

The hypothesis-testing component of the present study uses multivariate analysis techniques to test the hypothesized model. Regression analysis is used as a common method of analyzing and describing the relationship between a response variable and one or more explanatory variables (Everitt, 2009). In this type of model, one estimates the probability of an event occurring. In view of the research objectives for this project, it was considered that binary logistic regression would be an appropriate analysis method for examining and predicting individuals' choice behavior. In this case, this refers to whether an individual decides to frequently use s-commerce (coded as 1) or not (coded as 0 ). These are types of regression models in previous ICT innovation adoption studies, such as those on enterprise systems adoption (Ramdani, 2008) and e-business adoption (Zhu, Kraemer \& Xu, 2003).

\subsection{Data Collection}

The data collection was initiated in August 2017 via online survey. The subjects for this study were individuals engaged in SNSs, including students and working and unemployed individuals. A pilot study was conducted with 11 individuals.

Table 3. Demographics of respondents $(\mathrm{N}=325)$.

\begin{tabular}{cccc}
\hline Characteristics & Options & Frequency & Percent \\
\hline \multirow{2}{*}{ Age } & Less than 20 & 16 & 4.9 \\
& $20-29$ & 170 & 52.3 \\
& $30-39$ & 63 & 19.4 \\
& More than 40 & 76 & 23.4 \\
& Working & 135 & 41.5 \\
\hline \multirow{2}{*}{ Job } & Student & 93 & 28.6 \\
& Unemployed & 39 & 12 \\
& Other & 58 & 17.8 \\
\multirow{2}{*}{ Social networking site usage frequency } & Daily & 311 & 95.7 \\
& One & 7 & 2.2 \\
& Rare & 7 & 2.2 \\
& Male & 185 & 56.9 \\
\hline \multirow{2}{*}{ Gender } & Female & 140 & 43.1 \\
\hline
\end{tabular}

This approach to developing the research instrument allowed us to refine questions and wordings to ensure they were clearly understood by respondents. In total, 325 responses were gathered. There were no missing data in the sample because participants could not submit their responses with missing values. Table 3 reviews the demographic information of the sample. Participants were almost balanced in terms of gender distribution (male: $56.9 \%$, female: $43.1 \%$ ), and the majority of participants were between 20 and 29 years of age (52.3\%). Furthermore, $41.5 \%$ of participants were workers, and $95.7 \%$ of participants were using SNSs daily.

\section{Results}

Given a set of predictors, (Hair et al., 2006) argue that the main objective of logistic regression is to achieve the highest prediction accuracy of the dependent variable's outcome. Compared to similar techniques, the logistic 
model requires fewer assumptions to produce a high predictive accuracy.

Based on the Social support theory and TAM model of individuals' adoption of social commerce, the logistic regression model is specified as follows:

$$
\text { In }\left(\mathrm{P}_{\mathrm{i}} / 1-\mathrm{P}_{\mathrm{i}}\right)=\beta_{0}+\beta_{1} . \mathrm{PU}_{\mathrm{i}}+\beta_{2} . \mathrm{PEOU}_{\mathrm{i}}+\beta_{3} . \mathrm{PIQ}_{\mathrm{i}}+\beta_{4} \cdot \mathrm{SCC}_{\mathrm{i}}+\varepsilon_{\mathrm{i}}
$$

Logistic regression helps to predict the probabilities of decision-making and measures how well the independent variables explain the dependent variable (Pallant\& Manual, 2010). Table 4 below shows the output of binary logistic regression.

The results show that perceived usefulness and social commerce constructs are significant. Therefore, the results suggest that these factors are related to the likelihood of intention to use s-commerce. To find the goodness of fit and to measure the strength of association between independent and dependent variables, statistical tests, including Cox and Snell $\mathrm{R}^{2}$ and Nagelkerke $\mathrm{R}^{2}$, were used. Table 4 shows complete information on the usefulness of the model. The values of the Cox and Snell R Square and Nagelkerke R Square provide an indication of the variation in the dependent variable explained by the model. In this model, the two values are 0.29 and 0.39 for the Cox and Snell and Nagelkerke, respectively. This value is in line with previous works (e.g., Premkumar, 2003; Ramdani, 2008).

Table 4. Logistic regression

\begin{tabular}{|c|c|c|c|c|}
\hline Independent variable & $\underline{\mathbf{B}}$ & Wald & Sig. & $\underline{\operatorname{Exp}(B)}$ \\
\hline Perceived usefulness & $1 . \overline{7} 90$ & 33.984 & .000 & 5.987 \\
\hline Perceived information quality & -.539 & 3.551 & .060 & .583 \\
\hline Social commerce construct & 1.243 & 13.041 & .000 & 3.466 \\
\hline Perceived ease of use & .065 & .042 & .838 & 1.068 \\
\hline $\begin{array}{l}\text { Nagelkerke R Square } \\
\text { Cox and Snell R Square }\end{array}$ & $\begin{array}{c}391.0 \\
0.293 \\
\text { Predicted s-con }\end{array}$ & ce adoption & & \\
\hline Observed & Nonadopters & Adopters & Percentage Correct & \\
\hline Nonadopters & 99 & 55 & 64.3 & \\
\hline Adopters & 37 & 134 & 78.4 & \\
\hline Overall percentage & & & 71.7 & \\
\hline
\end{tabular}

Notes: *Variables are significant at the 0.05 level of significance.

Returning to the hypotheses posed in this paper, there is evidence of the importance of perceived usefulness and SCCs in individuals' usage intention regarding s-commerce services. Perceived usefulness and SCC factors are expected to be important enablers for s-commerce usage owing to the reputation of SNSs that using these tools wisely can help in saving individuals' time and effort. This was indeed found to be the case in our analysis. Shoppers may seek information about specific brands' or businesses' products or services before they actually purchase them; since the emergence of s-commerce, customers can easily do a quick search on their laptop or mobile device to find more information about what they want to buy (Wang \& Zhang, 2012). Because of s-commerce's usefulness, individuals will save the time and effort required to visit the physical location of the store to see the product and to ask the seller for more detailed information. Individuals can now find plenty of information about the product or service. They can find straightforward details about the pros and cons of the product using ratings and reviews. They can also ask directly for recommendations via online communities, and helpful reactions will arrive in a short while. Furthermore, via social networks, users are more likely to get discounted prices, user-specific advertising, and social-based interfaces, which are the unique characteristics of s-commerce as compared to traditional e-commerce (Lee \& Choi, 2014). The present findings are consistent with past research that reported on perceived usefulness and SCCs as significant factors for individuals' decision-making regarding the adoption of new technologies (e.g., Venkatesh, 2000; Gefen et al., 2003).

Perceived ease of use and perceived information quality factors are not strong determinants for predicting s-commerce adoption in this study. Regarding perceived ease of use, this finding differs from some published studies such as Yang (2005), Gefen et al. (2003), Sadia (2011), and Kim et al. (2009) that suggest perceived ease of use is an essential attribute of ICT innovation and that individuals will be more likely to adopt it if they are 
user friendly. Ashraf, Thongpapanl \& Razzaque (2015) maintain that in the early phase of adoption, perceived ease of use can be more important than perceived usefulness in motivating users to accept a technology and that its importance diminishes as users become familiar with the system. The insignificance of perceived ease of use as a point in favor of adoption might be because individuals take for granted that most SNSs are user-friendly and therefore cannot recognize this factor as a key facilitator for s-commerce usage. Alternatively, they may be used to it to the extent that they consider other determinants as much more important compared to this one. This result is in line with studies such as $\mathrm{Lu}$ (2014), which reported that perceived ease of use was not empirically supported as vital for continuance intention to use mobile commerce. When individuals are looking for information provided by other shoppers add about a specific product or service, they do not give attention to the ease of use on the business page, because most SNSs have almost the same manner of interaction and individuals are used to it. Neither do they give attention to the quality of the information that the seller will add to the business SNS page or website, because consumers can find the full details by searching for comments, reviews, and ratings from other consumers. For this reason, individuals do not consider the information that sellers provide on their websites or pages on SNSs as a major source of information in this case. Shoppers look for what the majority of other customers believe about specific products or services, and they probably look for a particular comment about a specific aspect of the product. Comments' and reviews' themes are almost the same in all social networks platforms and have little to do with the level of quality of the information that sellers provide. Former consumers' opinions about a particular product or service in online communities are what influence individuals' intention to buy.

\section{Discussion}

This study attempted to develop an individual s-commerce adoption model that was theoretically grounded in TAM and social support theory. By developing this model, the results of this research supported the idea that more than one context can be responsible for the decision by individuals to adopt a new ICT innovation (i.e., TAM model and SCC in this study). This research project can help to enrich people's knowledge and understanding of the s-commerce acceptance process in this era of rapid development of new technologies. The model adds new insights to the literature, highlights a number of managerial and academic implications, and concludes with specific suggestions for future research. To the best of our knowledge, this is among the first studies to explore the adoption of s-commerce in the context of individuals in Jordan. The nature of the situation in Jordan should also offer enough scope to partially generalize the findings beyond the geographical area considered for the study to people in other regions and even countries, because the Jordanian community is now considered an attractive area for people from different backgrounds and different countries. Besides, the advancement level of SNS usage and internet connectivity among Jordan residents.

\subsection{Implications for Technology Consultants and Business Managers}

This study provides important practical implications for technology consultants, social media specialists, and business owners. Individual consumers are an important source of income for firms. Businesses that fail to consider their interactions with s-commerce may lose their market share, because other businesses will reach their customers via social networks. Social media specialists should, therefore, be more focused on identifying appropriate role models, learning about the specific problems these businesses face, understanding businesses characteristics, taking a more proactive role in promoting successful diffusion in these businesses, and using the findings of this study to make businesses aware about consumers' buying behaviors on social networks. Publications that concentrate on shopping on SNSs suggest that the more buyers shop using SNSs, which they perceive to be useful, the more intention they have to buy (Cha, 2009). Understanding the factors affecting consumers' usage of s-commerce technologies will allow businesses to design rationalized strategies to handle s-commerce phenomena. Businesses may need to improve their interactions with consumers via social networks in an effort to not fall behind the rapid transformation of individual behavior regarding finding information about products and services. Businesses need to reflect on how to fully use the potential of s-commerce in their favor. SNSs features such as ratings, reviews, and recommendations and referrals via online forums have a powerful effect on purchasing decisions in both negative and positive ways. A significant factor that motivates buyers to use s-commerce is the existence of previous shoppers' ratings and reviews (Chen, Fay \& Wang, 2011); this is considered to be the main perceived usefulness for buyers. Recent attention has focused on highlighting the popularity of third-party product reviews. Researchers such as Chen et al. (2005) argue that consumers need for advertising information is vanishing because of reviews generated by third parties. In this case, s-commerce is a double-edged sword for businesses either because of negative ratings and reviews posing a major challenge for businesses or because of positive ratings and recommendations influencing potential buyers, which in turn rewards business's efforts to build a good reputation and market share. Thus, businesses should concentrate on 
online s-commerce and put more effort into improving their customer ratings and reviews to gain a better reputation and make their product or service a strong candidate for future recommendations. In fact, there are many benefits that businesses can earn through social networks, such as enhanced brand popularity (De Vries, Gensler \& Leeflang, 2012) and word-of-mouth communication about their products (Chen et al., 2011). This can lead to greater business reach, more sales, and a better reputation. Undoubtedly, s-commerce has become one of the most powerful influencers on purchasing decisions because it gives a voice to customers while developing their confidence.

\subsection{Study Limitations and Future Research Directions}

In this study, knowledge of ICT innovation adoption among individuals was discussed. Although the main aims and objectives of the study were fulfilled, many related areas of study and empirical researches could not be reviewed because of the study's limitations. Further research can build on the current study by examining s-commerce adoption in specific sectors in different countries by examining the supplementary face of s-commerce; for example, firm's readiness to s-commerce. Additionally, further studies can be done to determine how succession knowledge can be a major factor in influencing individuals' intention to buy. This study was limited to using online questionnaire surveys to achieve its objectives. Further research could be conducted to explore more barriers for s-commerce among individuals and small and medium businesses through a qualitative data collection method. Issues related to currently adopted ICT innovations such as e-commerce and s-commerce can be discussed through structured interviews and focus groups organized for selected individuals and social media specialists. Because s-commerce is relatively new, any further studies should take into consideration the fact that the number of managers, businesses, and social media specialists familiar with s-commerce has yet to reach a critical mass. This study focuses on the relationship between the constructs identified and the variables included in the study; however, these variables are not intended to be comprehensive. Rather, they are a representation of the key factors that potentially affect individuals' adoption of s-commerce. Other factors can also be included. Gefen et al. (2003) demonstrated that innovation acceptance is a multipart, inherently social developed process by examining individuals' perceptions of technology that have an effect on their usage intention. By facilitating technology implementation to address cognitive, emotional, and contextual concerns successfully and adding it to the social support theory and TAM model, the resulting framework gains the ability of the upcoming framework to predict willingness of individuals to use s-commerce.

\section{Acknowledgments}

This work was supported by the Deanship of Academic Research, The University of Jordan.

\section{References}

Ashraf, A. R., Thongpapanl, N., \& Razzaque, M. (2015). Adoption of online shopping: A technology acceptance perspective. In Ideas in marketing: Finding the new and polishing the old (pp. 826-826). Springer, Cham. https://doi.org/10.1007/978-3-319-10951-0_302

Bagozzi, R. P., \& Dholakia, U. M. (2002). Intentional social action in virtual communities. Journal of interactive marketing, 16(2), 2-21. https://doi.org/10.1002/dir.10006

Bailey, J. E., \& Pearson, S. W. (1983). Development of a tool for measuring and analyzing computer user satisfaction. Management science, 29(5), 530-545. https://doi.org/10.1287/mnsc.29.5.530

Beldad, A., De Jong, M., \& Steehouder, M. (2010). How shall I trust the faceless and the intangible? A literature review on the antecedents of online trust. Computers in human behavior, 26(5), 857-869. http://dx.doi.org/10.1016/j.chb.2010.03.013

Çelik, H. E., \& Yilmaz, V. (2011). Extending the technology acceptance model for adoption of e-shopping by consumers in Turkey. Journal of Electronic Commerce Research, 12(2), 152.

Cha, J. (2009). Shopping on social networking Web sites: Attitudes toward real versus virtual items. Journal of Interactive Advertising, 10(1), 77-93. https://doi.org/10.1080/15252019.2009.10722164

Chang, M. K., Cheung, W., \& Lai, V. S. (2005). Literature derived reference models for the adoption of online shopping. Information \& Management, 42(4), 543-559. http://dx.doi.org/10.1016/j.im.2004.02.006

Chen, J., Xu, H., \& Whinston, A. B. (2011). Moderated online communities and quality of user-generated content. Journal of Management Information Systems, 28(2), 237-268. http://dx.doi.org/10.2753/MIS0742-1222280209

Chen, Y., \& Xie, J. (2005). Third-party product review and firm marketing strategy. Marketing Science, 24(2), 218-240. http://dx.doi.org/10.1287/mksc.1040.0089 
Chen, Y., Fay, S., \& Wang, Q. (2011). The role of marketing in social media: How online consumer reviews evolve. Journal of Interactive Marketing, 25(2), 85-94. http://dx.doi.org/10.1016/j.intmar.2011.01.003

Cobb, S. (1976). Social support as a moderator of life stress. Psychosomatic medicine. http://dx.doi.org/10.1097/00006842-197609000-00003

Conner, M., \& Armitage, C. J. (1998). Extending the theory of planned behavior: A review and avenues for further research. Journal of applied social psychology, 28(15), 1429-1464. http://dx.doi.org/ 10.1111/j.1559-1816.1998.tb01685.x

Crocker, J., \& Canevello, A. (2008). Creating and undermining social support in communal relationships: the role of compassionate and self-image goals. Journal of personality and social psychology, 95(3), 555. http://dx.doi.org/10.1037/0022-3514.95.3.555

Davis, F. D. (1989). Perceived usefulness, perceived ease of use, and user acceptance of information technology. MIS quarterly, 319-340. http://dx.doi.org/10.2307/249008

De Vries, L., Gensler, S., \& Leeflang, P. S. (2012). Popularity of brand posts on brand fan pages: An investigation of the effects of social media marketing. Journal of interactive marketing, 26(2), 83-91. http://dx.doi.org/10.1016/j.intmar.2012.01.003

Everitt, B. S. (2009). Multivariable modeling and multivariate analysis for the behavioral sciences. CRC Press.

Flanagin, A. J., \& Metzger, M. J. (2013). Trusting expert-versus user-generated ratings online: The role of information volume, valence, and consumer characteristics. Computers in Human Behavior, 29(4), 1626-1634. http://dx.doi.org/10.1016/j.chb.2013.02.001

Füller, J., MüHlbacher, H., Matzler, K., \& Jawecki, G. (2009). Consumer empowerment through internet-based co-creation. Journal of Management Information Systems, 26(3), 71-102. http://dx.doi.org/10.2753/MIS0742-1222260303

Gefen, D., Karahanna, E., \& Straub, D. W. (2003). Trust and TAM in online shopping: An integrated model. MIS quarterly, 27(1), 51-90.

Hair, J. F., Black, W. C., Babin, B. J., Anderson, R. E., \& Tatham, R. L. (1998). Multivariate data analysis (Vol. 5, No. 3, pp. 207-219). Upper Saddle River, NJ: Prentice hall.

Hajli, M. (2012, March). Social Commerce Adoption Model. In UKAIS (p. 16).

Hajli, M. (2013). A research framework for social commerce adoption. Information Management \& Computer Security, 21(3), 144-154. http://dx.doi.org/10.1108/IMCS-04-2012-0024

Hajli, M. N. (2014). A study of the impact of social media on consumers. International Journal of Market Research, 56(3), 387-404. http://dx.doi.org/10.2501/IJMR-2014-025

Hajli, N. (2015). Social commerce constructs and consumer's intention to buy. International Journal of Information Management, 35(2), 183-191. http://dx.doi.org/10.1016/j.ijinfomgt.2014.12.005

Hajli, N., Lin, X., Featherman, M., \& Wang, Y. (2014). Social word of mouth: How trust develops in the market.

Jeppesen, L. B., \& Molin, M. J. (2003). Consumers as co-developers: Learning and innovation outside the firm. $\begin{array}{lllll}\text { Technology Analysis \& } \quad \text { Strategic } & \text { Management, } & \text { 15(3), }\end{array}$ https://doi.org/10.1080/09537320310001601531

Kim, D. J., Ferrin, D. L., \& Rao, H. R. (2009). Trust and satisfaction, two stepping stones for successful e-commerce relationships: A longitudinal exploration. Information systems research, 20(2), 237-257.

Kim, S., \& Park, H. (2013). Effects of various characteristics of social commerce (s-commerce) on consumers' trust and trust performance. International Journal of Information Management, 33(2), 318-332. https://doi.org/10.1016/j.ijinfomgt.2012.11.006

Kumar, R., Novak, J., \& Tomkins, A. (2010). Structure and evolution of online social networks. In Link mining: models, algorithms, and applications (pp. 337-357). Springer, New York, NY.

Lai, V. S., \& Li, H. (2005). Technology acceptance model for internet banking: An invariance analysis. Information \& management, 42(2), 373-386. http://dx.doi.org/10.1016/j.im.2004.01.007

Lee, H., \& Choi, J. (2014). Why do people visit social commerce sites but do not buy? The role of the scarcity heuristic as a momentary characteristic. KSII Transactions on Internet \& Information Systems, 8(7). http://dx.doi.org/10.3837/tiis.2014.07.010 
Liang, T. P., \& Turban, E. (2011). Introduction to the special issue social commerce: a research framework for social commerce. International Journal of electronic commerce, 16(2), 5-14. http://dx.doi.org/10.2753/JEC1086-4415160201

Lou, H., Luo, W., \& Strong, D. (2000). Perceived critical mass effect on groupware acceptance. European Journal of Information Systems, 9(2), 91-103. http://dx.doi.org/10.1057/palgrave.ejis.3000358

$\mathrm{Lu}$, J. (2014). Are personal innovativeness and social influence critical to continue with mobile commerce? Internet Research, 24(2), 134-159. http://dx.doi.org/10.1108/IntR-05-2012-0100

Lu, Y., Zhao, L., \& Wang, B. (2010). From virtual community members to C2C e-commerce buyers: Trust in virtual communities and its effect on consumers' purchase intention. Electronic Commerce Research and Applications, 9(4), 346-360. http://dx.doi.org/10.1016/j.elerap.2009.07.003

Mahmood, M. A. (1987). System development methods-a comparative investigation. MIS Quarterly, 293-311.

Miller, J., \& Doyle, B. A. (1987). Measuring the effectiveness of computer-based information systems in the financial services sector. MIS quarterly, 107-124. http://dx.doi.org/10.2307/248832

$\mathrm{Ng}$, C. S. P. (2013). Intention to purchase on social commerce websites across cultures: A cross-regional study. Information \& Management, 50(8), 609-620. https://doi.org/10.1016/j.im.2013.08.002

Noh, M., Lee, K., Kim, S., \& Garrison, G. (2013). Effects of collectivism on actual s-commerce use and the moderating effect of price consciousness. Journal of Electronic Commerce Research, 14(3), 244.

Pallant, J., \& Manual, S. S. (2010). A step by step guide to data analysis using SPSS. Berkshire UK: McGraw-Hill Education.

Park, D. H., Lee, J., \& Han, I. (2007). The effect of on-line consumer reviews on consumer purchasing intention: The moderating role of involvement. International journal of electronic commerce, 11(4), 125-148. http://dx.doi.org/10.2753/JEC1086-4415110405

Pavlou, P. A. (2003). Consumer acceptance of electronic commerce: Integrating trust and risk with the technology acceptance model. International journal of electronic commerce, $7(3)$. http://dx.doi.org/10.1080/10864415.2003.11044275

Poushter, J. (2016). Smartphone ownership and internet usage continues to climb in emerging economies. Pew Research Center, 22.

Premkumar, G. (2003). A meta-analysis of research on information technology implementation in small business. Journal of organizational computing and electronic commerce, 13(2), 91-121. https://doi.org/10.1207/S15327744JOCE1302_2

Qin, L. (2017). A Cross-Cultural Study of Interpersonal Trust in Social Commerce. Journal of Computer Information Systems, 1-8. https://doi.org/10.1080/08874417.2017.1383865

Ramdani, B. (2008). Technological, organisational and environmental factors influencing SMEs adoption of Enterprise Systems: a study in the Northwest of England (Doctoral dissertation, The University of Manchester).

Sadia, S. (2011). User acceptance decision towards mobile commerce technology: a study of user decision about acceptance of mobile commerce technology. Interdisciplinary Journal of Contemporary Research in Business, 2(12), 535-547.

Senecal, S., \& Nantel, J. (2004). The influence of online product recommendations on consumers' online choices. Journal of retailing, $80(2)$. http://dx.doi.org/10.1016/j.jretai.2004.04.001

Shen, J., \& Eder, L. B. (2012). An examination of factors associated with user acceptance of social shopping websites. User Perception and Influencing Factors of Technology in Everyday Life, 28. http://dx.doi.org/10.4018/978-1-4666-1954-8.ch004

Shen, Y. C., Huang, C. Y., Chu, C. H., \& Liao, H. C. (2010). Virtual community loyalty: An interpersonal-interaction perspective. International Journal of Electronic Commerce, 15(1), 49-74. http://dx.doi.org/10.2753/JEC1086-4415150102

Shih, H. P. (2004). An empirical study on predicting user acceptance of e-shopping on the Web. Information \& Management, 41(3), 351-368. http://dx.doi.org/10.1016/S0378-7206(03)00079-X

Srinivasan, A. (1985). Alternative measures of system effectiveness: Associations and implications. MIS quarterly, 243-253. http://dx.doi.org/10.2307/248951 
Swamynathan, G., Wilson, C., Boe, B., Almeroth, K., \& Zhao, B. Y. (2008, August). Do social networks improve e-commerce? A study on social marketplaces. In Proceedings of the first workshop on Online social networks (pp. 1-6). ACM. http://dx.doi.org/10.1145/1397735.1397737

Todri, V., \& Adamopoulos, P. (2014). Social commerce: An empirical examination of the antecedents and consequences of commerce in social network platforms.

United States Department of Commerce. (2014). Doing Business in Jordan: 2014 Country Commercial Guide for U.S. Companies.

Venkatesh, V. (2000). Determinants of perceived ease of use: Integrating control, intrinsic motivation, and emotion into the technology acceptance model. Information systems research, 11(4), 342-365. https://doi.org/10.1287/isre.11.4.342.11872

Venkatesh, V., Morris, M. G., Davis, G. B., \& Davis, F. D. (2003). User acceptance of information technology: Toward a unified view. MIS quarterly, 425-478.

Wang, C., \& Zhang, P. (2012). The evolution of social commerce: The people, management, technology, and information dimensions. CAIS, 31(5).

Yang, K. C. (2005). Exploring factors affecting the adoption of mobile commerce in Singapore. Telematics and informatics, 22(3), 257-277. https://doi.org/10.1016/j.tele.2004.11.003

Yaseen, H., Dingley, K., \& Adams, C. (2016). Capturing the growth of e-commerce in Jordan using a novel research approach. International Journal of Management and Commerce Innovations, 3(2), 811-827.

Zhang, H., Lu, Y., Gupta, S., \& Zhao, L. (2014). What motivates customers to participate in social commerce? The impact of technological environments and virtual customer experiences. Information \& Management, 51(8), 1017-1030. https://doi.org/10.1016/j.im.2014.07.005

Zhu, K., Kraemer, K., \& Xu, S. (2003). Electronic business adoption by European firms: A cross-country assessment of the facilitators and inhibitors. European Journal of Information Systems, 12(4), 251-268. http://dx.doi.org/10.1057/palgrave.ejis.3000475

\section{Copyrights}

Copyright for this article is retained by the author(s), with first publication rights granted to the journal.

This is an open-access article distributed under the terms and conditions of the Creative Commons Attribution license (http://creativecommons.org/licenses/by/4.0/). 